\title{
The Plurinational State in Ecuador
}

\author{
Brittany Dreyer
}

The Indigenous rights movement in Ecuador forged a participatory political model that led to democratic institutions becoming responsive to the multiethnic nature of their country, and in doing so, created a model for Latin American countries suffering Indigenous repression as a long term consequence of colonialism. Political crises in the country have defined Ecuador as one of the most unstable countries in Latin America. ${ }^{1}$ This insinuates that the Ecuadorian Indigenous movement is a vital example for understanding the global context because it has been one of the most successful new social movements in Latin America. It also presents the idea of a plurinational state, which is a core aspect for Ecuador's Indigenous people and many other Indigenous people in similar Latin American countries. This paper will explain the extent to which Indigenous groups in Ecuador aided in the conception of a modern and successful social movement, which can be applied to the global context.

As is the case in all examples of colonialism and political rule by a minority, the political and economic life of the majority of the people has been disrupted much more than the material culture and religious beliefs of the culture. ${ }^{2}$ During the Spanish colonization of Latin America, the Spanish decimated the Inca population, who had strong ties to the land that their ancestors had lived on for many generations. As Cesar Verduga, Ecuador's Minister of Government, claimed: "The Amazon region has a very fragile ecology, and to continue colonization would

\footnotetext{
${ }^{1}$ Nancy Grey Postero and Leon Zamosc, The Struggle for Indigenous Rights in Latin America (Brighton: Sussex Academic Press, 2004), 131.

${ }^{2}$ John Gillen, "Quichua-speaking Indians of Northern Ecuador," American Anthropologist Volume 38 (1936), 551.
} 
destroy it." ${ }^{3}$ In 1992, Verduga helped negotiate land title claims for the population of Quichua in the northern region of Ecuador, which include the Achuar and Shiwiar groups that populate a significantly sparse area of the Amazon. ${ }^{4}$

While Indigenous activists began to demand education programs as early as the 1920s, it was not until the 1950s that the formal process of Indigenous organization began, leading to local community associations that spurred the spread of activism on regional and provincial levels. ${ }^{5}$ The central reason for Indigenous activism in this time period was a direct response to the arrival of oil companies such as Petro-Canada and, most importantly, agrarian reform. As a result of this, 207 families formed a ranching cooperative in 1977 to create a government to manage their modernization projects and the state granted them almost 42000 hectares of their ancestral land. ${ }^{6}$

This cooperative inspired the slogan, "Sólo unidos venceremos!" (Only united will we overcome!). ${ }^{7}$ Although this slogan suggests revolutionary beginnings for the organization, the Rukullakta cooperative's President Shiguango did not want to publicise the slogan, as it would thereby align the cooperative with the political Left, and in relation, communist rhetoric. Aligning with communist ideals would have been devastating for the cooperative, as the Rukullakta knew, due to the Cold War stance held by the United States. The example of Guatemala epitomizes the fact that the United States would invoke the Monroe Doctrine, which supposedly endows them with the right to intervene in South and Central American countries without opposition from European powers.

Instead, the cooperative chose a title that translates to "Our history of living together in a large group," which emphasizes the need for cooperation as a single political entity to achieve

\footnotetext{
${ }^{3}$ James Brooke, "Ecuador Gives Indians Title to Big Amazon Area," The New York Times (1992).

${ }^{4}$ Ibid.

${ }^{5}$ Postero and Zamosc, The Struggle for Indigenous Rights in Latin America, 134.

${ }^{6}$ Suzana Sawyer, Crude Chronicles (Duke University Press, 2004).

${ }^{7}$ Juliet S. Erazo, Governing Indigenous Territories: Enacting Sovereignty in the Ecuadorian Amazon. (Durham:

Duke University Press, 2013), xviii.
} 
and hold onto the sovereignty of their ancestral lands. ${ }^{8}$ The Indigenous leaders pursued greater autonomy through utilizing the Ecuadorian government, as they did not seek isolation or independence from relationships of power. These Indigenous groups worked towards sovereignty by forming alliances with other governments, agencies, and willing NGOs, such as the Ministry of Education, which contributed funds for public schools equal to those of other groups in Ecuador. ${ }^{9}$ Cooperative leaders became managers of large plots of land, large development projects, and state-funded public programs. Therefore, in this sense, the Indigenous struggle for autonomy in Ecuador is more accurately defined as an effort to increase local control over education and development of infrastructure in Indigenous communities.

The political structure of Indigenous communities, such as the Kichwa, began to shift from small family groups to state-run organizations that included thousands of citizens. ${ }^{10}$ Additionally, leaders became involved in health and education programs, beginning with the Peasants' Health Insurance Program, the Seguro Campesino, which provided reduced costs to hospital care and prescription medicine. ${ }^{11}$ In this perspective, Rukullakta leaders perceived themselves as governors of a territory as early as the 1970s, with the ability to set economic policies, and took this position very seriously in shaping the community.

With the return to democracy in Ecuador in 1979, parliamentary authority was confusing due to the number of presidents from different parties succeeding each other. The confusion led to a sense of class struggle which was rooted in regional, ideological and personal ideals between groups. ${ }^{12}$ As is true in the case of Ecuador, Indigenous rights movements have not been limited to cultural identity or ethnic rights, but have transcended these goals in order to attain recognition

\footnotetext{
${ }^{8}$ Erazo, Governing Indigenous Territories, xix.

${ }^{9}$ Ibid., 2.

${ }^{10}$ Ibid., 65.

11 Ibid., 77.

${ }^{12}$ Postero and Zamosc, The Struggle for Indigenous Rights in Latin America, 132.
} 
of broader social issues and political power struggles. ${ }^{13}$ Thereby, the modern Indigenous movements can be seen as archetypes of new social movements around the world, as they involve broad issues such as the environment, human rights, education and women's rights.

As ethnic Indigenous groups in Ecuador and Latin America in general are diverse in language and culture, the demand for a plurinational state is integral to their Indigenous rights movements. The most important step in achieving this political structure was the formation of the Confederation of Indigenous Nationalities of Ecuador (CONAIE) in $1986,{ }^{14}$ which unified the variety of Indigenous groups and distinct "nationalities." This embodied the plurinational concept of the coexistence of two or more nationalities within a political formation. There were few Latin American countries that had unified Indigenous confederations during this time, and none had such an alarming influence as the CONAIE. Under the government of Social Democrat President Rodrigo Borja from 1988 to 1992, CONAIE was able to establish a national bilingual education program in the Indigenous areas of the country. ${ }^{15}$ As well, CONAIE's demands included improvements in the social and economic situation of Indigenous communities, as land, agriculture, healthcare and infrastructure had largely been neglected because of the lack of representation in the government.

It was only in the 1990s that a highly organized Indigenous movement arose out of their struggles with American oil companies. By the 1990s, Ecuador had become the third largest foreign supplier of oil to the western portion of the United States. ${ }^{16}$ As a result, Ecuador spurred neoliberal reforms that ultimately led to a crisis of governance, accountability, and

\footnotetext{
${ }^{13}$ Postero and Zamosc, The Struggle for Indigenous Rights in Latin America, 132.

${ }^{14}$ Kenneth P. Jameson, "The Indigenous Movement in Ecuador: The Struggle for a Plurinational State," Latin American Perspectives Vol. 38, No. 1, A Second Look at Latin American Social Movements. (Sage Publications Incorporated, January 2011), 65.

${ }^{15}$ Postero and Zamosc, The Struggle for Indigenous Rights in Latin America, 134.

${ }^{16}$ Sawyer, Crude Chronicles.
} 
representation, which inspired one of Latin America's strongest Indigenous movements in the twentieth century. ${ }^{17}$

The June 1990 protest epitomized the turning point in Ecuadorian politics, as Indigenous people from all around Ecuador protested in Quito to demand their cultural and ethnic rights as Indigenous peoples. This organization was their first mass mobilization that shocked Ecuador for several days. The mobilization paralyzed major roads and commercial activities in various capital cities of Ecuador for nearly a week. ${ }^{18}$ The key reasons for the uprising included protesting the high cost of living, the low prices received for Indigenous products, and the lack of solutions regarding land conflicts. ${ }^{19}$ As a result of the uprising, the Borja government was forced to negotiate with CONAIE by endorsing land acquisition programs.

While this was a considerable gain, in 1992 CONAIE again led a march along with Indigenous people in Quito until Borja agreed to set definite boundaries and titles to their lands. This mass protest did not represent a sudden outburst of political unrest, but was the result and culmination of the Indigenous political organization throughout the twentieth century, due to the lasting colonial practice of racial and ethnic discrimination. ${ }^{20}$ This mass protest was a symptom of the crisis of representation that occurred within Ecuador, as public sectors that have traditionally been excluded from governmental representation, such as the Indigenous population, expressed their demands to aid in political decisions. ${ }^{21}$ With this perspective, civil protest was the only method by which to express their dissatisfaction and opposition to their political situation and lack of land recognition.

\footnotetext{
${ }^{17}$ Sawyer, Crude Chronicles.

${ }^{18}$ Emma Cervone, Long Live Atahualpa: Indigenous Politics, Justice and Democracy in the Northern Andes (Durham: Duke University Press, 2012), 16.

${ }^{19}$ Postero and Zamosc, The Struggle for Indigenous Rights in Latin America, 134.

${ }^{20}$ Cervone, Long Live Atahualpa, 16.

${ }^{21}$ Postero and Zamosc, The Struggle for Indigenous Rights in Latin America, 143.
} 
The uprising of 1990 represented the maturation of the Indigenous political mobilization in Ecuador, and elevated the Indigenous struggle for human rights and presence in the political sphere to the national level. ${ }^{22}$ The Indigenous movement in Ecuador influenced changes in civil society, and began to exercise social and political influence on the government. This influence exceeded the demographic weight of the population of Indigenous peoples that it was meant to represent, as the 2001 national census claimed that ethnic and self-identified Indigenous account for less than 10 percent of the population of Ecuador. ${ }^{23}$

As is similarly reflected with many other Latin American countries, such as Guatemala and Colombia, Indigenous political struggles have had a considerable influence on the redefinition of their respective nations in terms of democracy and multiculturalism. ${ }^{24}$ The example of Ecuador's experience with ethno-politics to gain Indigenous rights and recognition presents a vital modern precedent for other countries, especially those within Latin America, due to their similar ethnic and historical basis with multiple ethnicities and political systems.

In 1995, CONAIE created a new political party which was to be based on the Indigenous movement itself. The party was named the Pachakutik Movement of Plurinational Unity. As Pachakutik means "time of resurgence" in the native Quechua language, the creation of this new Indigenous party epitomizes the rise of Indigenous rights in political and civic representation. ${ }^{25}$ The Pachakutik party made a successful debut in the 1996 election, as they received 10 percent of seats in the national congress and significantly more representation at the provincial level. ${ }^{26}$ This represents a watershed moment for Indigenous groups in Ecuador due to the fact that the Pachakutik party was able to secure vital positions of regional power in the areas proportionally

\footnotetext{
${ }^{22}$ Cervone, Long Live Atahualpa, 17.

${ }^{23}$ Postero and Zamosc, The Struggle for Indigenous Rights in Latin America, 133.

${ }^{24}$ Ibid.

${ }^{25}$ Ibid., 136.

${ }^{26}$ Postero and Zamosc, The Struggle for Indigenous Rights in Latin America, 136.
} 
more populated by Indigenous people. The crisis of representation in the government was slightly averted, as the Pachakutik party supported the interests of popular sectors and the traditionally underrepresented population of Ecuador. This ensured that the Indigenous groups received adequate political representation in the communities that they live in and was a considerable step for the Indigenous groups involved.

While President Abdalá Bucaram created the Ministry of Indian Affairs in 1996 in opposition to their rising representation in government, the Pachakutik party supported reforms of Indigenous social, political, and cultural rights. In 1997, they passed reforms which defined Ecuador as a multicultural state, and ensured provisions on territoriality of land and participation in the variety of state groups. ${ }^{27}$ With this perspective, these reforms meant that Indigenous groups were provided with a certain degree of autonomy over their own lands.

The Indigenous movement in Ecuador was able to provide leadership for the Indigenous population, as CONAIE was able to align the struggle for Indigenous rights with that of other agrarian organizations. In the latter half of the 1990s, CONAIE included the unions and other groups and was able to broaden its discourse to represent the demands of a larger population as a result. This organized alliance formed in opposition to the rise of neoliberal reforms that were occurring in the 1990s, and show that the Indigenous movement strategically led this opposition to further the goals of all parties.

The Indigenous movement in Ecuador has been historically distinct in comparison to others in Latin America. The popular struggles never escalated to radicalism and have not questioned private property, the class structure, or the capitalist economy. ${ }^{28}$ This concept presents the idea that the Indigenous movement's struggles were defensive, and were undertaken

\footnotetext{
${ }^{27}$ Postero and Zamosc, The Struggle for Indigenous Rights in Latin America, 137.

${ }^{28}$ Ibid., 144.
} 
in order to prevent deterioration of the political situation. CONAIE's rise to leadership was monumental for the Indigenous rights movement in Ecuador, as they achieved many of their aspirations regarding Indigenous status. These accomplishments included the definition of Ecuador as a plurinational state, representation within institutions, official native languages, and control over health, education, and development. The Indigenous Rights Movement in Ecuador was especially successful, and shows that the Confederation for Indigenous Nationalities in Ecuador's contribution was vital for both agrarian groups as well as Indigenous peoples. 


\section{Bibliography}

James, Brooke. "Ecuador Gives Indians Title to Big Amazon Area.” The New York Times. 1992.

Cervone, Emma. Long Live Atahualpa: indigenous politics, justice and democracy in the Northern Andes. Durham: Duke University Press, 2012.

Erazo, Juliet S. Governing indigenous territories: enacting sovereignty in the Ecuadorian Amazon. Durham: Duke University Press, 2013.

Gillen, John. "Quichua-Speaking Indians of Northern Ecuador." American Anthropologist Volume 38, 1936.

Jameson, Kenneth P. "The Indigenous Movement in Ecuador: The Struggle for a Plurinational State." Latin American Perspectives Vol. 38, No. 1, A Second Look at Latin American Social Movements. Sage Publications Incorporated, January 2011.

Postero, Nancy G. and Leon Zamosc. The Struggle for Indigenous Rights in Latin America. Brighton: Sussex Academic Press, 2004.

Sawyer, Suzana. Crude Chronicles: Indigenous Politics, Multinational Oil, and Neoliberalism in Ecuador. Duke University Press, 2004.

Selverston-Scher, Melina. Ethnopolitics in Ecuador: Indigenous Rights and the Strengthening of Democracy. Miami: North South Center Press, 2001. 